\title{
Selective changes in the $\alpha$-adrenoceptor-mediated contraction in the senescent rat urinary bladder
}

\author{
Tomomi Aita, Akira Ishihata ${ }^{*}$, Akiko Yamada, Yumi Katano \\ Division of Theoretical Nursing and Pathophysiology, Yamagata University School of Medicine, Yamagata, Japan; \\ *Corresponding Author: ishihata@med.id.yamagata-u.ac.jp
}

Received 30 July 2012; revised 28 August 2012; accepted 6 September 2012

\begin{abstract}
The urinary bladder is innervated and functionally regulated by the autonomic nervous system. In order to elucidate the mechanism of functional changes in aged rat urinary bladder, we studied the influence of senescence on, 1) the $\alpha$-adrenergic contractile response to phenylephrine in the urinary bladder body and trigone, 2) the muscarinic contractile response to carbachol in the body and trigone. The binding characteristics of $\left[{ }^{3} \mathrm{H}\right]$ quinuclidinyl benzilate (QNB) to muscarinic cholinoceptors were compared in young and aged bladder. Bladders from young (2 - 3 month-old) and aged (27 month-old) male Fischer 344 rats were isolated, cut into strips and mounted in the organ bath, then the developed tension was recorded. Histologically, the aged bladder did not show pathologic changes such as inflammation and hypertrophy. Carbachol-induced contraction in aged rat bladder was identical to that obtained in young rat. In the receptor binding assay, $\left[{ }^{3} \mathrm{H}\right] \mathrm{QNB}$ maximal binding capacity and $\mathrm{Kd}$ value were not significantly changed in aged bladder. In contrast, a selective $\alpha$-adrenergic agonist phenylephrine, elicited greater contractions both in the aged body and trigone than those in young rats. The augmentation of $\alpha$-adrenoceptor-mediated contractions in aged bladder may induce urinary dysfunction such as voiding difficulty.
\end{abstract}

Keywords: Bladder; Smooth Muscle; Aging; $\alpha$-Adrenoceptor; Muscarinic Receptor

\section{INTRODUCTION}

It is important to study the mechanism of urinary bladder dysfunctions such as urinary incontinence, pollakisuria (urinary frequency) and residual urine (incomeplete voiding), because these problems increase with aging and affect the quality of life in elderly people [1]. The maximal voiding rate and the contractility of urinary bladder are decreased, and the uninhibited bladder contraction is frequently observed in aged people [2]. However, the mechanism of the age-related changes in urinary bladder function is not yet elucidated in detail.

The urinary bladder consists of two regions: bladder body and bladder base (trigone). The urinary bladder is innervated and functionally regulated by sympathetic and parasympathetic nerves. During the phase of urine storage, adrenergic nerves mainly play a crucial role $[3,4]$. Norepinephrine released from adrenergic nerve endings, relaxes bladder body by increasing intracellular cAMP via $\beta$-adrenergic receptors widely expressed in the bladder body, and contracts bladder base and proximal urethra via $\alpha$-adrenergic receptors to prevent premature bladder emptying. The $\alpha_{1}$ adrenergic receptor stimulates phosphatidylinositol turnover and increased diacylglycerol activates protein kinase $\mathrm{C}$, while increased inositoltrisphosphate mobilize $\mathrm{Ca}^{2+}$ to cause smooth muscle contraction. In contrast, cholinergic nerves play primarily in the phase of voiding $[3,4]$. Acetylcholine released from cholinergic nerve endings, contracts the smooth muscle of bladder body via activation of muscarinic receptors to cause voiding. The muscarinic receptor-mediated contraction of smooth muscle is induced by activation of protein kinase $\mathrm{C}$ and by increased intracellular $\mathrm{Ca}^{2+}$. On the other hand, adrenergic activity is inhibited in this phase, leading to relax proximal urethra for voiding.

In order to elucidate the mechanisms of age-related changes in urinary bladder function, we studied the influence of aging on the contractile response to muscarinic and $\alpha$-adrenergic stimulation, and on the binding characteristics of $\left[{ }^{3} \mathrm{H}\right]$ quinuclidinyl benzilate $\left(\left[{ }^{3} \mathrm{H}\right] \mathrm{QNB}\right)$ to muscarinic cholinoceptors, in addition to histological examination in rat urinary bladder.

We revealed that the muscarinic receptor-mediated response was not affected by aging, while the contractile response to $\alpha$-adrenergic stimulation was significantly augmented in both bladder body and trigone. 


\section{METHODS}

\subsection{Drugs Used}

$\left[{ }^{3} \mathrm{H}\right]$ quinuclidinyl benzilate $(2.22 \mathrm{TBq} / \mathrm{mmol})$ was purchased from New England Nuclear (Boston, MA, USA). Atropine sulfate monohydrate was from Wako Pure Chemicals (Osaka, Japan). Carbachol, phenylephrine, prazosin, propranolol were obtained from Sigma Chemical Co. (St. Louis, MO).

\subsection{Measurement of Carbachol-Induced Contraction, and Phenylephrine-Induced Contraction in Urinary Bladder}

Male young (2 - 3 months) and aged (27 months) Fischer 344 rats obtained from Charles River Japan (Atsugi, Japan) were used. Experiments were performed in accordance with the Guide for Care and Use of Laboratory Animals published by the US National Institute of Health (NIH Publication No. 85-23, revised 1996) and under the regulations of the Animal Care Committee of Yamagata University School of Medicine. Rats were killed under anesthesia with ether. Urinary bladder was isolated, and excess fat and connective tissues were re-moved. The urinary bladder was cut to three strips from body and one strip from trigone. Each bladder strip was suspended in organ baths $\left(37^{\circ} \mathrm{C} \pm 0.1^{\circ} \mathrm{C}\right)$ containing $10 \mathrm{ml}$ physiological salt solution. The solution contained $118 \mathrm{mM} \mathrm{NaCl}, 4.7 \mathrm{mM} \mathrm{KCl}, 24.9 \mathrm{mM} \mathrm{NaHCO}{ }_{3}, 1.18$ $\mathrm{mM} \mathrm{MgSO}$, $1.18 \mathrm{mM} \mathrm{KH}_{2} \mathrm{PO}_{4}, 11.1 \mathrm{mM}$ glucose, 1.8 $\mathrm{mM} \mathrm{CaCl}_{2}$ and $0.057 \mathrm{mM}$ ascorbic acid. High concentration of $\mathrm{K}^{+}$solution was made by substituting $\mathrm{NaCl}$ with equimolar $\mathrm{KCl}$. These solutions were saturated with $95 \%$ $\mathrm{O}_{2}$ and $5 \% \mathrm{CO}_{2}$ at $37^{\circ} \mathrm{C}$ to $\mathrm{pH}$ 7.4. The developed ten-sion was recorded with an isometric force transducer (7T15-240, Orientec, Tokyo, Japan) for measurement of changes in the contractile force. The preparation was stretched to a resting tension of $1.0 \mathrm{~g}$, and the solution was changed every $15 \mathrm{~min}$. After an equilibration period of $1 \mathrm{~h}$, each preparation was contracted with $66.7 \mathrm{mM}$ $\mathrm{KCl}$ (high $\mathrm{K}^{+}$) repeatedly until reproducible contraction was attained. To study the muscarinic receptor-mediated contraction, carbachol $\left(10^{-10}-3 \times 10^{-5} \mathrm{M}\right)$ was added cumulatively in the presence of both $\alpha$-adrenergic recaptor antagonist prazosin $\left(10^{-7} \mathrm{M}\right)$ and $\alpha$-adrenergic recaptor antagonist propranolol $\left(10^{-6} \mathrm{M}\right)$ to obtain the concentration-response curves.

To study the $\alpha$-adrenergic receptor-mediated contraction, phenylephrine $\left(10^{-8} \mathrm{M}-3 \times 10^{-4} \mathrm{M}\right)$ was added cumulatively in the presence of both $\alpha$-adrenergic antagonist propranolol $\left(10^{-6} \mathrm{M}\right)$ and muscarinic antagonist atropine $\left(10^{-7} \mathrm{M}\right)$ to obtain the concentration-response curve.

\subsection{Muscarinic Receptor Assay in Young and Aged Rat Bladder}

Urinary bladders were excised from rats and cut into 1 - $2 \mathrm{~mm}$ pieces, then homogenized in ice-cold buffer $(25$ $\mathrm{mM}$ Tris-HCl, $10 \mathrm{mM} \mathrm{MgCl} 2, \mathrm{pH}$ 7.4) by using a Polytron (Kinematica, Luzern, Switzerland) three times for 15 sec at setting 7. The supernatant was filtered through 4 layers of buffer-soaked cheesecloth. The protein concentration of the homogenate obtained was determined by the method of Lowry et al. [5]. The final protein concentration was adjusted to $1 \mathrm{mg} / \mathrm{ml}$ with buffer. The binding assay was carried out as follows: $\left[{ }^{3} \mathrm{H}\right]$ quinuclidinyl benzilate (QNB) was used to characterize the muscarinic receptors. The incubation mixture contained $50 \mu \mathrm{l}$ of membrane suspension, $50 \mu \mathrm{l}$ of 5 increasing concentration of $\left[{ }^{3} \mathrm{H}\right] \mathrm{QNB}(0.25-4 \mathrm{nM})$ and $150 \mu$ lof Tris-bufferd solution with or without muscarinic receptor antagonist atropine. Incubation was started by adding the membrane suspension to the assay mixture and carried out at $25^{\circ} \mathrm{C}$ for $60 \mathrm{~min}$. The reaction was terminated by adding $2 \mathrm{ml}$ of ice-cold Tris-buffered solution, followed by rapid vacuum filtration over a $0.2 \%$ albumin-containing Trisbuffer-soaked Whatman GF/C filter by use of an M-24R type cell harvester (Brandel Biochemical Research \& Development Laboratories, Gaithersburg, MD, USA). After the rapid filtration, the filter was rinsed three times with $4 \mathrm{ml}$ aliquots of the solution, dried for $60 \mathrm{~min}$ at $80^{\circ} \mathrm{C}$ and placed on scintillation vials. The radioactivity bound to the membrane was counted in ACS-II (Amersham, Arlington Heights, IL, USA) by a scintillation counter (Tri-Carb 2300 TR, Packard, Downers Grove, IL, USA). Nonspecific binding of $\left[{ }^{3} \mathrm{H}\right] \mathrm{QNB}$ was defined as radioactivity in the presence of $1 \mu \mathrm{M}$ of atropine. Specific binding of $\left[{ }^{3} \mathrm{H}\right] \mathrm{QNB}$ was defined as total binding radioactivity minus nonspecific binding.

\subsection{Histological Examination}

Urinary bladders were isolated from young and aged rats. Each bladder was divided into body and trigone, and fixed overnight in $10 \%$ formaldehyde at $4^{\circ} \mathrm{C}$. Tissues were embedded in paraffin and cut into $4 \mu \mathrm{m}$ thick crosssections. Microscopic examination of hematoxylin-eosin and elastica-Masson trichrome-stained sections was performed to assess histological changes in bladders.

\subsection{Statistical Analysis}

Data were expressed as means \pm SEM. To compare the data, unpaired Student's t-test or Welch's t-test was used. The difference was defined to be statistically significant when a $P$ value was less than 0.05 . 


\section{RESULTS}

\subsection{The $\mathrm{KCl}$ - and Carbachol-Induced Contraction in Aged Bladder Body and Trigone}

The maximal bladder contraction was obtained by high concentration $(66.7 \mathrm{mM})$ of $\mathrm{KCl}$ in bladder body (young: $3.0 \pm 0.3 \mathrm{~g}, \mathrm{n}=8$; aged: $3.1 \pm 0.3 \mathrm{~g}, \mathrm{n}=6$ ) and trigone (young: $2.2 \pm 0.3 \mathrm{~g}, \mathrm{n}=8$; aged: $2.6 \pm 0.3 \mathrm{~g}, \mathrm{n}=6$ ). No age-related changes were observed in $66.7 \mathrm{mM} \mathrm{KCl}$-elicited contractions (Figure 1). Therefore, the concentration-response curves for carbachol in young and aged bladder were depicted as percentage of maximal response to $\mathrm{KCl}\left(\% \mathrm{KCl}_{\max }\right)$. Aging did not affect the contractile response to carbachol in either bladder body or trigone. The maximal responses to carbachol were $145.1 \% \pm$ $17.7 \%(\mathrm{n}=8)$ in young and $157.0 \% \pm 13.8 \%(\mathrm{n}=6)$ in aged bladder body (Figure 2A), and 121.2\% $\pm 14.1 \%$ ( $=11)$ in young and $135.0 \% \pm 15.6 \%(\mathrm{n}=7)$ in aged bladder trigone (Figure 2B). Also, the $\mathrm{EC}_{50}$ values were not different between young and aged bladder (Table 1).

\subsection{Binding Characterization of Muscarinic Receptor}

To confirm the results obtained from physiological experiments of carbachol-induced contraction in isolated bladder, we tested whether the muscarinic receptors were altered in aged rat. The saturation binding experiment was carried out using $\left[{ }^{3} \mathrm{H}\right] \mathrm{QNB}$ as a radioactive probe for muscarinic receptors. Scatchard analysis was done to calculate the parameters for QNB binding. The results indicated that $\mathrm{B}_{\max }$ values of $50.7 \pm 3.4,49.8 \pm 4.5$ $\mathrm{fmol} / \mathrm{mg}$ protein, and $\mathrm{K}_{\mathrm{d}}$ values of $0.26 \pm 0.05,0.22 \pm$ $0.04 \mathrm{nM}$ in young and aged bladder, respectively $(\mathrm{n}=4$, each, Figure 3).
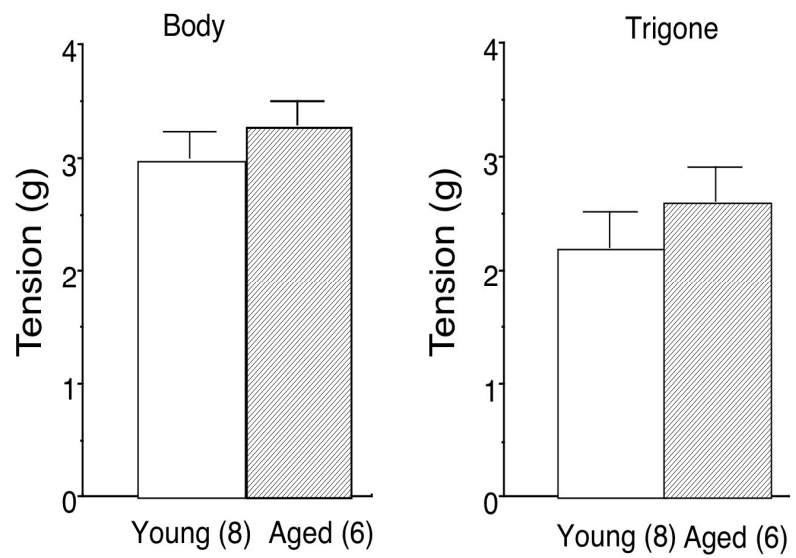

Figure 1. High $\mathrm{K}^{+}(66.7 \mathrm{mM})$-induced maximal contraction of young and aged bladder. Left: bladder body; Right: bladder trigone. Values are means \pm SEM. Number of animals are in parentheses.
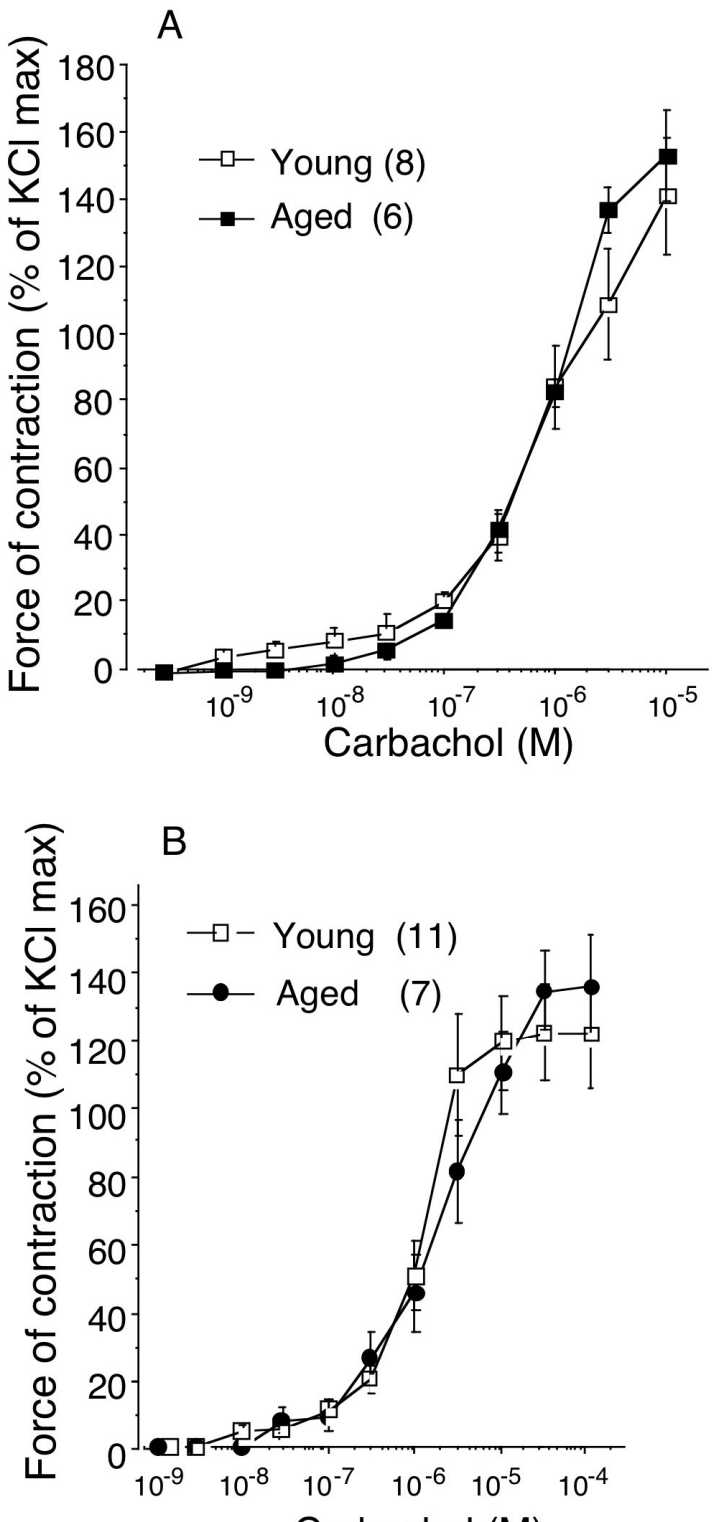

Carbachol (M)

Figure 2. Concentration-response curves for carbacholinduced contraction in young and aged bladder. The developed tension was expressed as percentage of 66.7 $\mathrm{mM} \mathrm{KCl-induced} \mathrm{contraction.} \mathrm{A:} \mathrm{bladder} \mathrm{body;} \mathrm{B:} \mathrm{blad-}$ der trigone. Data are represented as means \pm SEM. Number of animals are in paren-theses (Young: 8 - 11; Aged: 6 - 7).

Table 1. The carbachol-induced contraction in bladder body and trigone of young and aged rat.

\begin{tabular}{ccccc}
\hline & \multicolumn{2}{c}{$\mathrm{E}_{\max }\left(\%\right.$ of $\left.\mathrm{KCl}_{\max }\right)$} & \multicolumn{2}{c}{$\mathrm{EC}_{50}\left(\times 10^{-7} \mathrm{M}\right)$} \\
\hline Portion & Young & Aged & Young & Aged \\
\hline Body & $145.1 \pm 17.7$ & $157.0 \pm 13.8$ & $6.8 \pm 2.6$ & $9.1 \pm 1.6$ \\
Trigone & $121.2 \pm 14.1$ & $135.0 \pm 15.6$ & $7.2 \pm 1.1$ & $6.9 \pm 1.2$ \\
\hline
\end{tabular}

Data are represented as means \pm SEM. Number of animals (Young: $8-11$; Aged: 6 - 7). 
A
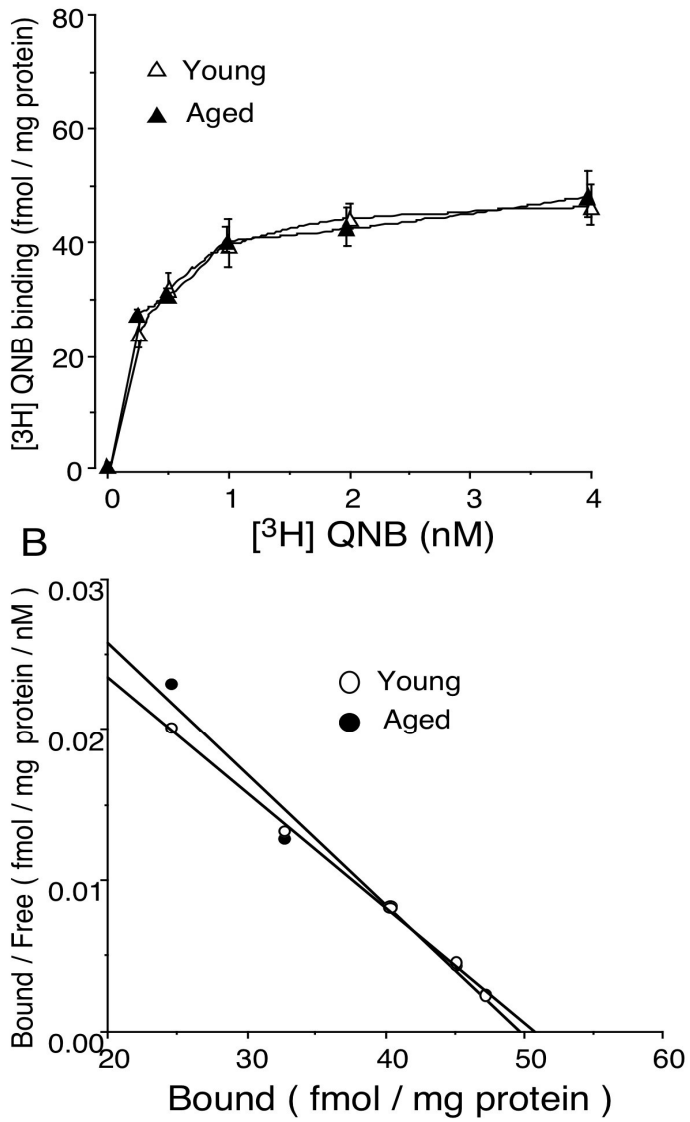

Figure 3. (A) Saturation binding of $\left[{ }^{3} \mathrm{H}\right] \mathrm{QNB}$ to muscarinic receptors in young and aged rat bladder. Data are represented as means \pm SEM of three independent experiments with triplicate measurement; (B) Scatchard plot analysis for bindings of $\left[{ }^{3} \mathrm{H}\right] \mathrm{QNB}$ to muscarinic receptors in young and aged rat bladder. The bladder membrane preparations were incubated with increasing concentrations of $\left[{ }^{3} \mathrm{H}\right] \mathrm{QNB}$ ranging from 0.25 to $4.0 \mathrm{nM}$ for $60 \mathrm{~min}$ at $25^{\circ} \mathrm{C}$.

\subsection{The Phenylephrine-Induced Contraction in Aged Bladder Body and Trigone}

The concentration-response curves for phenylephrine in young and aged bladder were depicted as percentage of maximal response to $\mathrm{KCl}\left(\% \mathrm{KCl}_{\max }\right)$. In contrast to the carbachol-induced contraction, aging increased the contractile response to phenylephrine in bladder body as well as trigone. The maximal responses to phenylephrine in bladder body were $24.2 \% \pm 2.9 \%(\mathrm{n}=13)$ in young rat and $36.3 \% \pm 6.0 \%(\mathrm{n}=8, \mathrm{P}<0.05)$ in aged rat. In trigone, the maximal responses to phenylephrine were also significantly increased in aged rat $(86.3 \% \pm 4.3 \%, \mathrm{n}$ $=6, \mathrm{P}<0.01)$ compared with young rat $(58.9 \% \pm 6.4 \%$, $\mathrm{n}=8$ ) (Figure 4). The $\mathrm{EC}_{50}$ values for phenylephrine-induced contraction were not different between young and aged trigone (Table 2).
A

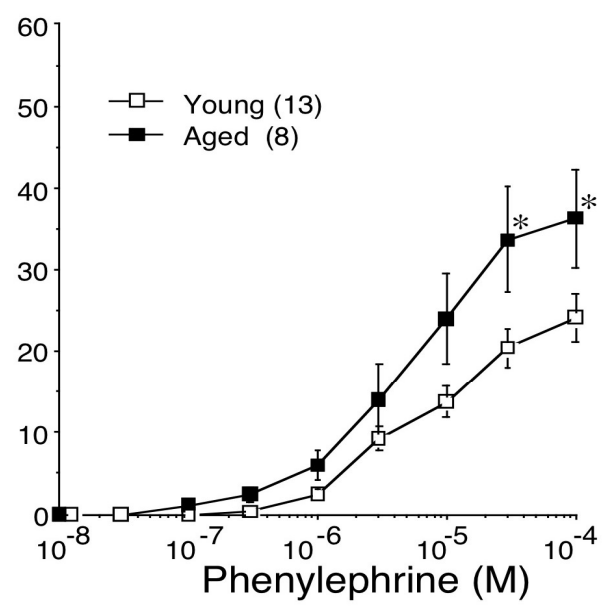

B

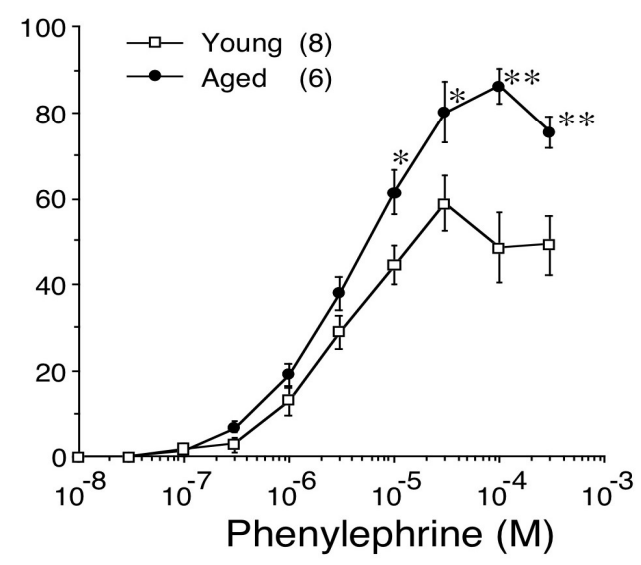

Figure 4. Concentration-response curves for phenylephrine induced contraction in young and aged bladder. The developed tension was expressed as percentage of $66.7 \mathrm{mM} \mathrm{KCl}$-induced contraction. A: bladder body; B: bladder trigone. Values are represented as means \pm SEM of the force of contraction ( $\%$ of maximal response to $66.7 \mathrm{mM} \mathrm{KCl}$ ). Number of animals in parentheses (Young: 8 - 11; Aged: 6). ${ }^{*} \mathrm{P}<0.05$ (vs. young).

Table 2. The phenylephrine-induced contraction in bladder body and trigone of young and aged rat.

\begin{tabular}{ccccc}
\hline & \multicolumn{2}{c}{$\mathrm{E}_{\max }\left(\%\right.$ of $\left.\mathrm{KCl}_{\max }\right)$} & \multicolumn{2}{c}{$\mathrm{EC}_{50}\left(\times 10^{-7} \mathrm{M}\right)$} \\
\hline Portion & Young & Aged & Young & Aged \\
\hline Body & $24.2 \pm 2.9(13)$ & $36.3 \pm 6.0^{*}(8)$ & $7.2 \pm 1.1(13)$ & $6.9 \pm 1.2(8)$ \\
Trigone & $58.9 \pm 6.4(8)$ & $86.3 \pm 4.3^{* *}(6)$ & $4.6 \pm 0.9(8)$ & $4.3 \pm 0.7(6)$ \\
\hline
\end{tabular}

Data are represented as means \pm SEM. Number of animals (Young: $8-13$, Aged: $6-8)$. ${ }^{*} \mathrm{P}<0.05,{ }^{* *} \mathrm{P}<0.01$ vs. young rat.

\subsection{Histological Examination of Bladder}

Sections of bladder bodies and trigones were stained with hematoxylin-eosin and elastica-Masson trichrome 
(Figure 5). There were no inflammatory cells infiltrated around vessels in aged bladder. Smooth muscles did not show hypertrophic changes in aged body and trigones. However, a relative thickening in the urothelium was observed in aged trigone compared with young trigone.

\section{DISCUSSION}

Aging affects the function of urinary bladder, for example, the maximal voiding rate and the contractility are decreased, and residual bladder volume is increased [2]. Several reports indicated that both alpha-adrenergic receptor and muscarinic receptor existed not only in bladder body but also in trigone [6-8]. However, there are no confidential results whether $\alpha$-adrenergic as well as muscarinic receptors play a role in age-related functional changes of urinary bladder.

In this study, we investigated whether the bladder contraction mediated by muscarinic and alpha-adrenergic receptors are differentially altered by aging, and whether bladder body and trigone are affected in a different manner.

\subsection{Changes in the $\mathrm{KCl}$-Induced Bladder Contraction in Aged Body and Trigone}

$\mathrm{KCl}$-induced contraction was compared in young and aged bladders, because $\mathrm{KCl}$ depolarized smooth muscle by opening the voltage-dependent $\mathrm{Ca}^{2+}$ channels and not by receptor-operated mechanism. This study showed that aging did not influence the $\mathrm{KCl}$-induced contraction in both bladder body and trigone. These results indicate that bladder contraction via voltage-dependent $\mathrm{Ca}^{2+}$ channel was not affected in aged rat. In accordance with the present study, it is reported that $\mathrm{KCl}$-induced isotonic contraction was not altered by aging $[7,9]$.

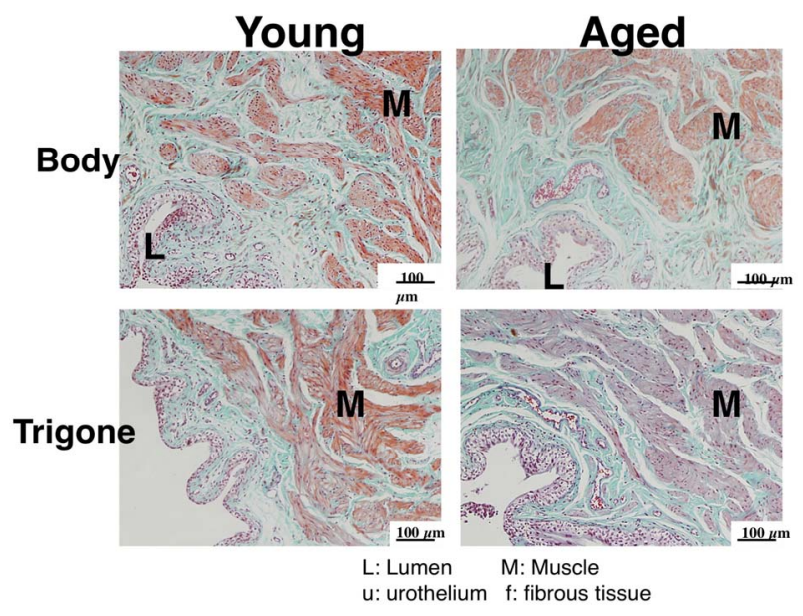

Figure 5. Elastica-Masson trichrome-stained bladder sections from young (left) and aged (right) rat. Each bladder was divided into body (upper panel) and trigone (lower panel), and fixed overnight in $10 \%$ formaldehyde at $4^{\circ} \mathrm{C}$. Tissues were embedded in paraffin and cut into $4 \mu \mathrm{m}$-thick cross-sections.

\subsection{Muscarinic Receptor-Mediated Bladder Contraction in Body and Trigone}

The maximal response and $\mathrm{EC}_{50}$ values for carbacholinduced contractions were not altered in aged bladder either in bladder body or in trigone. These results suggest that aging did not diminish the contractility of bladder smooth muscle via muscarinic receptor. However, there are several conflicting reports concerning the effect of aging on the muscarinic function in rat bladder. For example, in bladder trigone, Ordway et al. examined the muscarinic agonists (acetylcholine, bethanechol, oxotremorine)-induced contraction in 7, 16 and 27 month-old Fischer 344 rats, and reported that maximal contraction was augmented by aging without change in $\mathrm{EC}_{50}$ values [7]. In bladder body, other groups reported that muscarinic receptor-mediated maximal response in longitudinal detrussor muscle was diminished in aged Sprague-Dawley rats [10] and Fischer 344 rats [11]. These discrepancies may be due to the difference in the ages and strains of rats used, in the site of bladder, and in the method for evaluating the maximal contraction (with or without normalization by $\mathrm{KCl}$-induced contraction).

There are five subtypes of muscarinic receptors cloned (M1 to M5), and three subtypes (M1, M2, M3) are identified pharmacologically [12]. In human detrusor muscle, M2 receptors existed three times more than M3 receptors according to the immunoprecipitation study [13]. The receptor binding assay also indicated that the percentages of M2 and M3 receptors were $60 \%-80 \%$ and $20 \%-40 \%$, respectively $[14,15]$. Braverman et al. reported that M2 muscarinic receptor contributed to rat urinay bladder contraction [16]. However, the muscarinic subtype responsible for the carbachol-induced contraction in human bladder is thought to be M3 subtype [3]. We got the same results in the young bladder body: the carbachol-induced contraction was inhibited in the presence of $\mathrm{p}-\mathrm{F}-\mathrm{HHSiD}$ (M3 muscarinic receptor antagonist). The response curve for carbachol-induced contraction was shifted to the right in a concentration-dependent manner. Schild plot analysis showed that the slope of the regression line for $\mathrm{p}-\mathrm{F}$ HHSiD was 0.98 , which was not different from unity (data not shown). On the other hand, methoctramine (M2 muscarinic receptor antagonist) inhibited little the carbachol-induced contraction. This observation was carried out only in the young bladder body because muscarinic receptor binding characteristics and the contractile responses were not changed in aged bladder.

\subsection{Changes in Muscarinic Receptors in Aged Body and Trigone}

To support the results of physiological contraction study, receptor binding assay was carried out in the membrane preparation of whole bladder. In accordance with 
the contraction study, the muscarinic receptor density $\left(\mathrm{B}_{\max }\right)$ and its affinity $\left(\mathrm{K}_{\mathrm{d}}\right)$ were not altered in the aged rat. In contrast to our present result, Kolta et al. (1984) reported the age-related increase in muscarinic receptor of 7 , 17 and 29 month-old-rats [6]. On the other hand, Hayes et al. (1983) reported no age-related changes in muscarinic receptor of Sprague-Dawley rats [17]. However, these previous reports as well as the present study measured the muscarinic receptor of the whole bladder, so it can not be excluded that aging affects muscarinic receptor density in a region (body or trigone)-specific manner.

\subsection{Alpha-Adrenergic Receptor Mediated Contraction in Bladder Body and Trigone}

In contrast to the unaffected muscarinic receptor-mediated contraction, we have indicated that alpha-adrenergic receptor-mediated contraction was significantly increased not only in the body but also in the trigone of aged rat. In bladder body, previous reports also suggested that alphaadrenergic receptor-mediated contraction was augmented by aging $[8,18]$. In the voiding phase, bladder body is contracted via muscarinic receptor stimulation, while bladder base (trigone) is relaxed by inhibition of alphaadrenergic receptor. When the bladder body contracts to flow the urine out, the alpha $a_{1}$-adrenergic receptor-mediated hypercontractility of aged bladder trigone may cause dysfunction of voiding, resulting in the increased residual volume and urinary frequency. Two subtypes of alpha-adrenergic receptor are known (alpha $a_{1}$ and $\mathrm{alpha}_{2}$ ). In human bladder trigone and urethra, alpha ${ }_{1}$ adrenergic receptor is dominant [3]. In this study, phenylephrineinduced contraction of bladder body was inhibited by prazosin (a selective antagonist of alpha ${ }_{1}$-adrenergic receptor), suggesting that alpha ${ }_{1}$-adrenergic receptor exists not only in trigone but also in bladder body. In addition, it is known that among alpha ${ }_{1}$ receptor, alpha ${ }_{1 \mathrm{~A}}$ receptor is involved in contraction of human and rat urethra and prostatic smooth muscle $[8,19,20]$. Based on these reports and our present result indicating the equivalent $\mathrm{EC}_{50}$ values for alpha-receptor-mediated contractions, it is suggested that age-related increase in contraction of bladder body and trigone may be due to age-related increase in alpha $a_{1}$ receptor (probably alpha $\mathrm{1}_{\mathrm{A}}$ ). Although alpha-adrenergic receptor density in the hyper-reflex human detrusor muscle was shown to be increased [21], there is no report on the age-related changes in alphaadrenergic receptor density of bladder trigone. Because hyper-reflex bladder increases with aging, it may be possible that alpha-adrenergic receptor density increases in aged bladder. Further studies including alpha $a_{1}$ receptor assay and identification of subtype of alpha $a_{1}$ receptor are needed to elucidate the exact mechanism. We could not reveal the mechanism of the increased phenylephrineinduced contractions in bladder trigone as well as bladder body of aged rat, but Dmitrieva et al. reported the greater expression of alpha $1 \mathrm{D}$ adrenergic receptors in aged rat, especially in the urothelium [22]. The phenylephrine-induced increase in bladder pressure was reported to be inhibited by BMY7378 (alpha ${ }_{1 \mathrm{D}}$ adrenergic receptor antagonist) in old rat compared to young rat.

\subsection{Histological Changes}

Histological examination suggested that there were no inflammatory changes or smooth muscle hypertrophic changes in old male F344 rat. In contrast to the present study, a significant increase in the mean thickness of the muscularis layer and a significant decrease in the collagen density were reported in 30-month-old female Wistar rats [23]. In human bladder, however, aging was associated with a decrease in the area density of smooth muscle: connective tissue ratio [24]. These discrepancies may be due in part to the difference in species, sex and rat strains used in experiments. It would be possible that age-related changes in bladder function is not attributed to histological changes such as increase in smooth muscle.

In conclusion, we revealed the differential changes in the contractile response to alpha-adrenergic stimulation not only in the body, but also in the trigone of aged rat bladder, while muscarinic receptor-mediated response was not affected by aging, in both bladder body and trigone. Further studies of the precise mechanism for facilitation of alpha-adrenergic receptor-mediated contractions may be necessary to investigate urinary dysfunction such as voiding difficulty in the aged urinary bladder. In addition, because various functional receptors such as cholinergic, adrenergic and purinergic receptors are expressed not only in bladder smooth muscle cells but also in the urothelial cells, it is important to reveal the role of these receptors and their age-related changes in the urothelium.

\section{ACKNOWLEDGEMENTS}

This study was supported in part by the Grant-in-Aid for Scientific Research (C) (No. 20590087, 24500846) from the Ministry of Education, Science, Sports and Culture, Japan.

\section{REFERENCES}

[1] Okamura, K., Usami, T., Nagahama, K., Maruyama, S. and Mizuta, E. (2002) "Quality of life" assessment of urination in elderly Japanese men and women with some medical problems using international prostate symptom score and king's health questionnaire. European Urology, 41, 411-419. doi:10.1016/S0302-2838(02)00061-1

[2] Mathias, H.D., Pfisterer, M.H.D., Griffiths, D.J., Schaefer, 
W. and Resnick, N.M. (2006) The effect of age on lower urinary tract function: A study in women. Journal of American Geriatrics Society, 54, 405-412. doi:10.1111/j.1532-5415.2005.00613.x

[3] Anderson, K.E. and Amer, A. (2004) Urinary bladder con-traction and relaxation: Physiology and pathophysiology. Physiological Review, 84, 935-986. doi:10.1152/physrev.00038.2003

[4] Anderson, K.E. and Wein, A.J. (2004) Pharmacology of the lower urinary tract: Basis for current and future treatments of urinary incontinence. Pharmacological Review, 56, 581-631. doi:10.1124/pr.56.4.4

[5] Lowry, O.H., Resevrough, N.J., Farr, A.L. and Tandall, R.J. (1951) Protein measurement with the folin phenol reagent. Journal of Biological Chemistry, 193, 265-275.

[6] Kolta, M.G., Wallace, L.J. and Gerald, M.C. (1984) Agerelated changes in sensitivity of rat urinary bladder to autonomic agents. Mechanism of Ageing and Development, 27, 183-188. doi:10.1016/0047-6374(84)90043-5

[7] Ordway, G.A., Esbenshade, T.A., Kolta, M.G., Gerald, M.C., Wallace and L.J. (1986) Effect of age on cholinergic muscarinic responsiveness and receptors in the rat urinary bladder. Journal of Urology, 136, 492-496.

[8] Suzuki, Y., Moriyama, N., Kanada, A., Okaya, Y., Kawabe, K. and Aisaka, K. (1999) The role of a1L-adrenoceptor in rat urinary bladder: Comparison between young adult and aged rats. Life Science, 65, 2553-2559. doi:10.1016/S0024-3205(99)00524-X

[9] Saito, M., Kondo, A. and Gotoh, M. (1991) Agererated changes in the rat detrusor muscle: The contractile response to inorganic ions. Journal of Urology, 146, 891894.

[10] Munro, D.D. and Wendt, I.R. (1993) Contractile and metabolic properties of longitudinal smooth muscle from rat urinary bladder and the effects of aging. Journal of Urology, 150, 529-536.

[11] Pagala, M.K., Tetsoti, L., Nagpal, D. and Wise, G.J. (2001) Aging effects on contractility of longitudinal and circular detrusor and trigone of rat bladder. Journal of Urology, 166, 721-727. doi:10.1097/00005392-200108000-00100

[12] Caulfield, M.P. and Birdsall, N.J.M. (1998) International union of pharmacology: XVII. Classification of muscarinic acetylcholine receptors. Pharmacological Review, 50, 279-290.

[13] Wang, P., Luthin, G.R. and Ruggieri, M.R. (1995) Muscarinic acetylcholine receptor subtypes mediating urinary bladder contractility and coupling to GTP binding proteins. Journal of Parmacology and Experimental Therapeutics, 273, 959-966.

[14] Chiarini, A., Budriesi, R., Bolognesi, ML., Minarini, A. and Melchiorre, C. (1995) In vitro characterization of tripitramine, a polymethylene tetraamine displaying high selectivity and affinity for muscarinic M2 receptors. British Journal of Pharmacology, 114, 1507-1517. doi:10.1111/j.1476-5381.1995.tb13378.x

[15] Hegde, S.S. and Eglen, R.M. (1999) Muscarinic receptor subtypes modulating smooth muscle contractility in the urinary bladder. Life Science, 64, 419-428. doi:10.1016/S0024-3205(98)00581-5

[16] Braverman, A.S., Luthin, G.R. and Ruggieri, MR. (1998) M2 muscarinic receptor contributes to contraction of the denervated rat urinary bladder. American Journal of Physiology, 275, R1654-R1660.

[17] Hayes, E.E., McConnell, J.A. and Benson, G.S. (1983) The effect of aging on cholinergic receptor binding in the rat urinary bladder. Neurourology and Urodynamics, 2, 311-315. doi:10.1002/nau.1930020407

[18] Ordway, G.A., Kolta, M.G., Gerald, M.C. and Wallace, L.J. (1986) Agerelated change in alpha-adrenergic responsive-ness of the urinary bladder of the rat is regionally specific. Neuropharmacology, 25, 1335-1340. doi:10.1016/0028-3908(86)90105-X

[19] Marshall, I., Burt, R.P. and Chapple, C.R. (1995) Noradrena-line contractions of human prostate mediated by alpha $_{1 \mathrm{~A}^{-}}\left(\right.$alpha $\left._{1 \mathrm{C}^{-}}\right)$adrenoceptor subtype. British Journal of Pharmacology, 115, 781-786. doi:10.1111/j.1476-5381.1995.tb15001.x

[20] Nasu, K., Miriyama, N. and Fukusawa, R. (1998) Quantification and distribution of a1-adrenoceptor subtype mRNAs in human proximal urethra. British Journal of Pharmacology, 123, 1289-1293. doi:10.1038/sj.bjp.0701731

[21] Restorick, J.M. and Mundy, A.R. (1989) The density of cholinergic and alpha and beta adrenergic receptors in the normal and hyper-reflexic human detrusor. British Journal of Urology, 63, 32-35. doi:10.1111/j.1464-410X.1989.tb05120.x

[22] Dmitrieva, N., Zhang, G. and Nagabukuro, H. (2008) Increased alpha $a_{1 \mathrm{D}}$ adrenergic receptor activity and protein expression in the urinary bladder of aged rats. World Journal of Urology, 26, 649-655. doi:10.1007/s00345-008-0292-x

[23] Lluel, P., Palea, S., Barras, M., Grandadam, F., Heudes, D., Bruneval, P., Corman, B. and Martin, D.J. (2000) Functional and morphological modifications of the urinary bladder in aging female rats. American Journal of Physiology, 278, R964-R972.

[24] Lepor, H., Sunarvadi, I., Hartanto, V. and Shapiro, E. (1992) Quantitative morphometry of the adult human bladder. Journal of Urology, 148, 414-417. 